\title{
UPPSALA NATURAL RADIOCARBON MEASUREMENTS V
}

INGRID U. OLSSON and PIYA PIYANUJ"

Fysiska Institutionen, Uppsala Universitet, Uppsala, Sweden

The following list covers most of the samples measured at the Uppsala $\mathrm{C}^{14}$ laboratory since the last list (Uppsala IV) except for all of the samples utilized for determining the increase of the $\mathrm{C}^{14 /} / \mathrm{C}^{12}$ ratio due to explosion of nuclear devices.

The technique used is the same as previously described by ()Isson (1958) and the pretreatment is that which has been used earlier (Uppsala IV).

The reference sample is $95 \%$ of the activity of the NBS oxalic-acid standard. Any corrections for apparent water ages are thus not included here, but will be discussed in the later papers dealing with the marine samples. Corrections for deviations from the normal $\mathrm{C}^{13} / \mathrm{C}^{12}$ ratio $(-25.0 \%$ in the $\mathrm{PDB}$ scale $)$ are applied for the unknown samples. Our oxalic-acid was measured by Craig (1961) and has a $\mathrm{C}^{13} / \mathrm{C}^{12}$ deviation of $-18.97 \%$ and corresponds to the accepted standardized value, $-19 \%$, which should be used for age determinations (Editorial Statement in Radiocarbon, v. 3). Four new combustions of oxalicacid have not shown any significant difference in their $\mathrm{C}^{13}$ content relative to oxalic-acid 1 sample measured by Craig.

The value $5570 \mathrm{yr}$ has been used for the half-life of $\mathrm{C}^{14}$. Results are expressed in years before 1950. Errors include the standard deviation $(\sigma)$ of the counted particles as well as the error in the $\delta \mathrm{C}^{13}$ values. When the activity is very low, so that $2 \sigma$ corresponds to a possibility of infinite age, $2 \sigma$ has been used instead of $\sigma$.

Several samples had to be diluted with C().2 from an old source to bring them to the normal working pressure of $3 \mathrm{~atm}$.

\section{ACKNOWLEDGMENTS}

Descriptions of the samples are based on information provided by those responsible for collecting and submitting them. Before the final manuscript was ready, most contributors were kind enough to read the draft and suggest improvements. Sincere thanks are due to them. Special thanks are also due Dr. R. Ryhage and his co-workers for making the $\mathrm{C}^{13} / \mathrm{C}^{12}$ determinations; Prof. K. Siegbahn, who has made it possible to do this work at the institute; and Statens Naturvetenskapliga Forskningsråd, which has given the laboratory financial support. The authors are indebted to Miss Helena Strindlund for taking part during the springtime 1964 and to Miss Birgitta Wallin and Miss Maud Söderman. (One of us (P.P.) would like to acknowledge a fellowship from Swedish Agency for International Assistance through the International Seminar for Research and Education in Physics.

* On leave from the Department of Physics, Chulalongkorn University, Bangkok, Thailand. 


\section{SAMPLE DESCRIPTIONS}

\section{GEOLOGIC SAMPLES}

\section{A. Mediterranean Area}

\section{Western Mediterranean Sea series}

Foraminifera tests from deep-sea cores. Coll. 1948 by Swedish Albatross Expedition (Pettersson) ; subm. by K. Gösta Eriksson, Kvartärgeologiska Inst., Uppsala Univ., Uppsala, Sweden. All present and previous samples of sediment core No. 210 are described by Eriksson (in press) and samples from the other sediment core No. 211 will be described later by Eriksson. The Foraminifera analyses were made by Todd (1958). Comment: to determine the most suitable choice of fractions for $\mathrm{C}^{1+4}$ dating most samples have been investigated after the material was separated into three or more fractions. Material from the Sahara has strongly contaminated the smaller fractions. Water free from $\mathrm{CO}_{2}$ has been used in the preparation (Eriksson and Olsson, 1963, Olsson and Eriksson, in press). (Other dates in this series are given in Lppsala I, II, III and IV.

\section{U-299. Core 21004, 181 to $192 \mathrm{~cm},>44 \mu \quad 11,660 \pm 260$$$
9710 \text { в.c. }
$$

Core 21004 ( $37^{\circ} 26^{\prime}$ N Lat, $01^{\circ} 05^{\prime}$ E Long), depth 181 to $192 \mathrm{~cm}$, depth in sea $2782 \mathrm{~m}$. Above this level Globigerina pachyderma disappear and appear again first after the postglacial climatic optimum; the amount of more warmtolerant species increases upwards. Comment: fraction $>44 \mu$ was used. Diluted. $\delta \mathrm{C}^{13}=-2.4 \%$.

$\begin{array}{ll}\text { U-490. Core } 21006,337 \text { to } 347 \mathrm{~cm},<2 \mu & 13,000 \pm 180 \\ \text { 11,050 в.c. }\end{array}$

The same sample as $\mathrm{U}-493$ but fraction $<2 \mu$ was used. $\delta \mathrm{C}^{13}=-8.8 \%$ c.

\section{U-491. Core 21006, 337 to $347 \mathrm{~cm}, 2-44 \mu \quad 19,830+380$}

17,880 в.с.

The same sample as $\mathrm{U}-493$ hut fraction $2-44 \mu$ was used. $\delta \mathrm{C}^{13}=-2.1 \%$.

\section{U-492. Core 21006, 337 to, $347 \mathrm{~cm}, 414-62,1500$ 8800 в.C.}

The same sample as $\mathrm{U}-493$ but fraction $44-62 \mu$ was used. Diluted. $\delta \mathrm{C}^{13}$ assumed $-2.0 \%$.

$$
\begin{array}{ll}
\text { U-493. Core } 21006,337 \text { to } 347 \mathrm{~cm},>62 \mu & 11,380 \pm 230 \\
9430 \text { в.c. }
\end{array}
$$

Core 21006 ( $37^{\circ} 26^{\prime} \mathrm{N}$ Lat, $01^{\circ} 05^{\prime} \mathrm{E}$ Long $)$, depth 337 to $347 \mathrm{~cm}$, depth in sea $2782 \mathrm{~m}$. Above this level the percentage of the cool-tolerant Foraminifera species Globigerina pachyderma decreases considerably and contemporaneously there is an increase in the number of warm-tolerant species. Comment: fraction $>62 \mu$ was used. Diluted. $\delta \mathrm{C}^{13}=-2.0 \%$. 
U-458. Core 21102, 102.5 to $109 \mathrm{~cm},<2 \mu$

$6450 \pm 160$

4500 в.c. $2.4 \%$.

The same sample as U-460 but fraction $<2 \mu$ was used. Diluted. $\delta \mathrm{C}^{13}=$

U-459. Core $21102,102.5$ to $109 \mathrm{~cm}, 2-44 \mu$

$13,210 \stackrel{+410}{-390}$

11,260 в.с. $-3.1 \%$.

The same sample as U-460 but fraction $2-44 \mu$ was used. Diluted. $\delta \mathrm{C}^{13}=$

U-460. Core $21102,102.5$ to $109 \mathrm{~cm},>44 \mu$

$3520 \pm 120$

1570 в.c.

Core $21102\left(35^{\circ} 55^{\prime} \mathrm{N}\right.$ Lat, $02^{\circ} 20^{\prime} \mathrm{W}$ Long $)$, depth 102.5 to $109 \mathrm{~cm}$, depth in sea $1325 \mathrm{~m}$. At this level there is a high, but upward slightly decreasing number of warm-tolerant species, a low content of cool-tolerant species and a large number of ubiquitous ones. Comment: fraction $>44 \mu$ was used. Diluted. $\delta \mathrm{C}^{13}=-2.4 \%$.

$$
\begin{array}{ll}
\text { U-457. Core } 21110,619 \text { to } 631 \mathrm{~cm},>44 \mu & 24,000 \begin{array}{l}
+1700 \\
\mathbf{- 1 4 0 0}
\end{array} \\
22,000 \text { в.c. }
\end{array}
$$

Core $21110\left(35^{\circ} 55^{\prime} \mathrm{N}\right.$ Lat, $02^{\circ} 20^{\prime} \mathrm{W}$ Long), depth 619 to $631 \mathrm{~cm}$, depth in sea $1325 \mathrm{~m}$. The foraminiferal assemblage is mainly cool-tolerant. Comment: fraction $>44 \mu$ was used. Diluted. $\delta \mathrm{C}^{13}=-1.7 \%$.

\section{U-456. Core 21115,931 to $941 \mathrm{~cm},>44 \mu$}

$\mathbf{3 0 , 8 0 0} \underset{\mathbf{2 2 0 0}}{+\mathbf{3 0 0 0}}$

$\mathbf{2 8 , 8 0 0}$ в.с.

Core $21115\left(35^{\circ} 55^{\prime} \mathrm{N}\right.$ Lat, $02^{\circ} 20^{\prime} \mathrm{W}$ Long), depth 931 to $941 \mathrm{~cm}$, depth in sea $1325 \mathrm{~m}$. The foraminiferal assemblage is mainly cool-tolerant. Comment: fraction $>44 \mu$ was used. Diluted. $\delta \mathrm{C}^{13}=-2.6 \%$.

\section{B. Spitsbergen}

\section{Vestspitsbergen series}

Shells and bones measured as a continuation of Vestspitsbergen series (Uppsala II, III and IV; Feyling-Hanssen and Olsson, 1959-1960) to determine the shoreline displacement. Shells coll. and subm. by Rolf FeylingHanssen; bones coll. 1960 by Feyling-Hanssen and Olsson. All altitudes are above mean sealevel.

\section{U-443. Gerritelva 363 c}

$9110 \pm 130$ 7160 в.с.

Astarte borealis from Gerritelva $\left(78^{\circ} 38^{\prime} \mathrm{N}\right.$ Lat, $16^{\circ} 51^{\prime} \mathrm{E}$ Long), Adolfsbukta, Billefjorden, Spitsbergen, alt $30.1 \mathrm{~m}$ (Feyling-Hanssen, 1955, p. 94-98). Coll. 1950. Comment: inner $34 \%$ was used. $\delta \mathrm{C}^{13}=0.4 \%$.

\section{U-442. Gerritelva 363 b}

$9440 \pm 200$

Shell layer surrounding the part used for U-443. Comment: layer corresponds to $22 \%$ of the shells. $\delta \mathrm{C}^{13}=0.1 \%$. 


\section{U-441. Gerritelva 363 a}

Shell layer surrounding the part used for U-442. Comment: layer corresponds to $18 \%$ of the shells; $26 \%$ was removed by washing. $\delta \mathrm{C}^{13}=-0.4 \%$.

U-462. Gerritelva 361 b

$7560 \pm 110$

5610 в.с.

Astarte borealis from Gerritelva $\left(78^{\circ} 38^{\prime} \mathrm{N}\right.$ Lat, $16^{\circ} 51^{\prime} \mathrm{E}$ Long), Adolfsbukta, Billefjorden, Spitshergen, alt $18.0 \mathrm{~m}$ (Feyling-Hanssen, 1955, p. 94-96). Coll. 1950. Comment: inner $37 \%$ was used. $\delta \mathrm{C}^{13}=13.8 \%$.

\section{U-461. Gerritelva 361 a}

$7050 \pm 110$

5100 в.C.

Shell layer surrounding the part used for U-462. Comment: layer corresponds to $23 \%$ of the shells; $40 \%$ was removed by washing. $\delta \mathrm{C}^{13}=7.8 \%$ c

\section{U-464. Kapp Linné 300 b}

$6630 \pm 170$

\section{0 в.c.}

Mytilus edulis from Kapp Linné ( $78^{\circ} 4^{\prime} \mathrm{N}$ Lat, $13^{\circ} 38^{\prime} \mathrm{E}$ Long), Isfjorden, Spitsbergen, alt 7.5 m. Coll. 1950. Comment: inner 10\% was used. Diluted. $\delta \mathrm{C}^{13}=-1.4 \%$.

\section{U-463. Kapp Linné 300 a}

$6700 \pm 110$

4750 в.c.

Shell layer surrounding the part used for U.464. Comment: layer corresponds to $60 \%$ of the shells; $30 \%$ was removed by washing. $\delta \mathrm{C}^{13}=-1.1 \%$ c.

\section{U-479. Kapp Wijk 377 b}

$4250 \pm 210$

Mytilus edulis from Kapp Wijk ( $78^{\circ} 36^{\prime} \mathrm{N}$ Lat, $15^{\circ} 9^{\prime}$ E Long), Dicksonfjorden, Spitsbergen, alt $3 \mathrm{~m}$ (Feyling-Hanssen, 1955, p. 6-7). Coll. 1950. Comment: part of inner $55 \%$ was used; $45 \%$ was removed by washing. Diluted. $\delta \mathrm{C}^{13}=-1.9 \%$.

\section{U-478. Kapp Wijk 377 a}

$4340 \pm 100$ 2390 в.C.

Another part of the inner $55 \%$ of the shells used for U-479. Diluted. $\delta \mathrm{C}^{13}=-0.8 \%$.

\section{U-467. Gipshuken 6016 b:3}

$$
\begin{aligned}
& 4400 \begin{array}{l}
+330 \\
-320
\end{array} \\
& 2450 \text { в.c. }
\end{aligned}
$$

Organic fraction of whalebone from Gipshuken $\left(78^{\circ} 27^{\prime} \mathrm{N}\right.$ Lat, $16^{\circ} 24^{\prime}$ E Long), Isfjorden, Spitsbergen, alt ca. $10 \mathrm{~m}$ (Feyling-Hanssen and Jørstad, 1950, p. 55-58). Coll. 1960. Sample buried. Comment: bone was treated with conc. $\mathrm{HCl}$ and this sample was precipitated from the solution at $\mathrm{pH} 4$ with some $\mathrm{NaOH}$. Diluted. $\delta \mathrm{C}^{13}=-30.2 \%$.

\section{Iceland series}

$$
\text { C. Iceland }
$$

Marine molluscs from raised beaches collected to date land uplift. Molluscs 
found in living position. Described by Einarsson in Kjartansson and others (1964). Subm. by Thorleifur Einarsson.

\section{U-412. Reykjavikurflugvöllur $c_{2}$}

$10,310 \pm 260$ 8360 в.c.

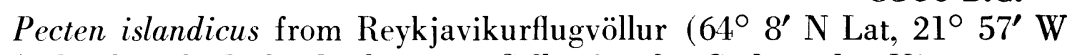
Long), Reykjavik, Iceland, alt $13 \mathrm{~m}$. Coll. 1963 by Gudmundur Kjartansson, Mus. of Nat. History, Reykjavik. Comment: inner $18 \%$ was used. Diluted. $\delta \mathrm{C}^{13}=0.5 \%$.

\section{U-415. Reykjavikurflugvöllur $\mathbf{c}_{1}$ \\ $10,230 \pm 190$ 8280 в.с.}

Pecten islandicus from same place as U-412. Comment: inner $21 \%$ was used. Diluted. $\delta \mathrm{C}^{13}=-7.6 \%$.

\section{U-414. Reykjavikurflugvöllur $\mathbf{b}_{1}$ \\ $10,450 \pm 160$ \\ 8500 в.C.}

Shell layer surrounding the part used for U-415. Comment: layer corresponds to $45 \%$ of the shells. $\delta \mathrm{C}^{13}=0.7 \%$.

\section{U-413. Reyk javikurflugvöllur $a_{1}$}

$9940 \pm 160$

7990 в.с.

Shell layer surrounding the part used for U-414. Comment: layer corresponds to $14 \%$ of the shells; $20 \%$ was removed by washing. $\delta \mathrm{C}^{13}=0.5 \%$.

\section{U-417. Hellisholtalækur b}

$9800 \pm 150$

7850 в.с.

Mytilus edulis from Hellisholtalækur $\left(64^{\circ} 8^{\prime} \mathrm{N}\right.$ Lat, $20^{\circ} 19^{\prime} \mathrm{W}$ Long), Arnessýsla, Iceland, alt $75 \mathrm{~m}$. Coll. 1939 and 1963 by Kjartansson and Einarsson. Comment: inner $29 \%$ was used. $\delta \mathrm{C}^{13}=-3.0 \%$.

\section{U-416. Hellisholtalækur a \\ $9580 \pm 140$ \\ 7630 в.с.}

Shell layer surrounding the part used for U-417. Comment: layer corresponds to $54 \%$ of the shells; $17 \%$ removed by washing. $\delta \mathrm{C}^{13}=-3.8 \%$.

\section{Storemosse series}

\section{Sweden}

Peat and gyttja from the raised bog Storemosse $\left(56^{\circ} 18^{\prime} \mathrm{N}\right.$ Lat, $15^{\circ} 19^{\prime}$ E Long), Ronneby parish, Blekinge, Sweden. The investigation was performed in order to date some horizons in a pollen diagram (especially the Sub-boreal and the Sub-atlantic part) from the central part of the bog. The samples from the uppermost $120 \mathrm{~cm}$ were taken in a cut wall. Other samples were cut out from a core (diam $6 \mathrm{~cm}$ ) taken by a piston sampler (type Borro). Depth given is that below surface of the bog. Coll. 1961 and subm. by Björn E. Berglund, Lunds Kvartärgeol. Inst., Lunds Univ., Lund, Sweden. Pollen analyzed by Berglund. The investigation of the vegetational history of this area will be published in Opera Botanica (Lund).

\section{U-448. Storemosse 10}

$$
\begin{array}{r}
380 \\
\text { A.D. } 1570
\end{array}
$$

Fresh Sphagnum-peat, 40 to $44 \mathrm{~cm}$. Sample from a Fagus minimum and the beginning of the Picea curve. $\delta \mathrm{C}^{13}=-24.1 \%$. 
U-481. Storemosse 18

Highly humified Sphagnum peat, 75 to $79 \mathrm{~cm}$. Sample dates a recurrence surface, a Fagus maximum and the beginning of the continuous Secale curve. $\delta \mathrm{C}^{13}=-25.5 \%$.

\section{U-1002. Storemosse 27}

$1200 \pm 50$

A.D. 750

Moderately humified Sphagnum peat, 111 to $115 \mathrm{~cm}$. Sample dating an increase of Fagus and decrease of Quercus and Tilia (probably just above the zone boundary Early/Late Sub-atlantic time). $\delta \mathrm{C}^{13}=-26.2 \%$.

U-447. Storemosse $39+40$

A.D. 370

$1580 \pm 80$

Fresh Sphagnum peat, 150 to $158 \mathrm{~cm}$. Sample below the zone boundary Early/Late Sub-atlantic time (just above a recurrence surface). $\delta \mathrm{C}^{13}=$ $-23.0 \%$.

U-480. Storemosse $48+49+50$

$2150 \pm 80$

200 B.C.

Fresh Sphagnum peat, 186 to $199 \mathrm{~cm}$. Sample dates end of a clearing phase. $\delta \mathrm{C}^{13}=-24.9 \%$.

\section{U-237. Storemosse 58}

$2400 \pm 90$

490 в.C.

Fresh Sphagnum peat, 230 to $234 \mathrm{~cm}$. Sample dates the beginning of a distinct clearing phase, approx. at the zone boundary Sub-boreal/Sub-atlantic time. $\delta \mathrm{C}^{13}=-24.4 \%$.

\section{U-449. Storemosse 78}

$2880 \pm 60$

930 в.с.

Amblystegium peat, 309 to $313 \mathrm{~cm}$. Sample dates a rising of ground-water level in Storemosse basin. $\delta \mathrm{C}^{13}=-27.1 \%$.

U-419. Storemosse 118

$9660 \pm 240$

7710 в.с.

Clayey algal gyttja, 475 to $477 \mathrm{~cm}$. Sample from zone boundary Younger Dryas/Preboreal. Comment: diluted. $\delta \mathrm{C}^{13}=-24.9 \%$.

\section{U-229. Storemosse 119}

$9490 \begin{array}{r}+310 \\ -300\end{array}$

7540 в.c.

Clayey algal gyttja, 477 to $479 \mathrm{~cm}$. Sample from zone boundary Younger Dryas/Preboreal. Comment: diluted. $\delta \mathrm{C}^{13}=-17.0 \%$.

U-230. Storemosse 127

$6810 \pm 130$

4860 в.c.

Peat and algal gyttja, 585 to $589 \mathrm{~cm}$, below a sandy layer. Supposed to be from the end of Alleröd. $\delta \mathrm{C}^{13}=-22.5 \%$. Comment: probably owing to the vacuum during the lifting of the sampler, the jacket has been filled with younger material instead of the very loose bottom material.

\section{U-440. Björkärr}

$3310 \pm 60$

1360 в.c.

Humous sand from Björkärr (56 $05^{\prime} \mathrm{N}$ Lat, $15^{\circ} 49^{\prime} \mathrm{E}$ Long), Torhamn 
parish, Blekinge, Sweden. Sample, 109 to $114 \mathrm{~cm}$ below surface, from an Early Sub-boreal shore ridge, ought to date the postglacial transgression maximum in southeastern Blekinge. Coll. 1963 and subm. by Berglund, $\delta \mathrm{C}^{13}=-25.9 \%$. Comment: the too young date is probably partly caused by downgrown roots. As much as almost $30 \%$ of the carbon must be of modern pre-bomb origin to cause an error of $1700 \mathrm{yr}$ of a $5000 \mathrm{yr}$-old sample.

\section{Östra Landborgen series}

Peat, wood and gyttja from layers covered by thick strata of sand and gravel (shore deposits originated from Lake Ancylus or Littorina Sea) to date the Ancylus transgression. Pollen analyses by Lars-König Königsson, Kvartärgeologiska Inst., Uppsala Univ., Uppsala, Sweden. Coll. and subm. by Königsson. Comment: these samples are the first ones in an extensive series. Another sample of particular interest in connection with this series is e.g. St-834 (9080 \pm 140; Stockholm V).

\section{U-431. Ākerby 1}

Wood from Åkerby $\left(56^{\circ} 43^{\prime} \mathrm{N}\right.$ Lat, $16^{\circ} 43^{\prime}$ E Long), Runsten parish, öland, Sweden. Sample, supposedly of Ancylus age, from a drift gyttja layer below a $3 \mathrm{~m}$ layer of gravel and sand. Coll. 1960: Comment: diluted. $\delta \mathrm{C}^{13}=$ $-26.3 \%$.

\section{U-487. Hulterstad 404}

$$
\begin{gathered}
10,670 \pm 150 \\
8720 \text { в.с. }
\end{gathered}
$$

Fen peat from Hulterstad parish ( $56^{\circ} 30^{\prime} \mathrm{N}$ Lat, $16^{\circ} 35^{\prime} \mathrm{E}$ Long), Öland, Sweden. Sample, supposed to be of pre-Ancylus time, from a fen peat layer below gravel and sand containing limnic molluscs. Coll. 1963. $\delta \mathrm{C}^{13}=-30.2 \%$.

\section{U-488. Mellösa 494}

$7650 \pm 120$

Peaty gyttja from Mellösa $\left(56^{\circ} 53^{\prime} \mathrm{N} \mathrm{Lat}, 16^{\circ} 50^{\prime} \mathrm{E}\right.$ Long), Bredsättra parish, Öland, Sweden. Sample, from period between Ancylus and Littorina transgressions, coll. below a layer with gravel and sand with marine molluscs. Coll. 1963. $\delta \mathrm{C}^{13}=-27.9 \%$.

\section{U-489. Mellösa 493}

$7570 \pm 120$ 5620 в.c.

\section{U-1016. Mellösa 493}

$7750 \pm 70$

$\mathbf{5 8 0 0}$ в.c.

Peat from Mellösa ( $56^{\circ} 53^{\prime} \mathrm{N}$ Lat, $16^{\circ} 50^{\prime} \mathrm{E}$ Long), Bredsättra parish, öland, Sweden. Sample from the peat immediately above the gyttja layer used for U-488. Coll. 1963. $\delta \mathrm{C}^{13}=-26.7 \%$.

\section{U-486. Övra Sandby 544}

Peat from Övra Sandby $\left(56^{\circ} 53^{\prime} \mathrm{N}\right.$ Lat, $16^{\circ} 49^{\prime} \mathrm{E}$ Long $)$, Bredsättra parish öland, Sweden. Sample from peat below a layer with gravel and sand. Coll. 1963. $\delta \mathrm{C}^{13}=-24.8 \%$ c. 


\section{Stora Alvaret series}

Peat and fen dy from shallow lakes in the almost treeless area, Stora Alvaret, on southern part of isle of öland in the Baltic, to date vegetational and cultural development as seen from pollen diagrams (Königsson, in preparation). Coll. and subm. by Königsson. Comment: these samples are the first ones in an extensive series. Some problems in connection with this series are discussed by Königsson (1962).

\section{U-444. Torpmosen A $1095 / 1097$}

$4080 \pm 90$

2130 в.c.

Fen dy from Torpmosen ( $56^{\circ} 32^{\prime} \mathrm{N}$ Lat, $16^{\circ} 35^{\prime}$ E Long), Stenåsa parish, Alvaret, öland, Sweden. Sample from 85 to $90 \mathrm{~cm}$ below surface below calcarous gyttja. Above this layer there are several layers of calcarous gyttja interrupted by peat or detritus gyttja. Pollen analysis implies zone boundary VII/VIII (Jessen) since sample is above Ulmus decrease. Coll. 1962. $\delta \mathrm{C}^{13}=$ $-27.3 \%$.

\section{U-1003. Torpmosen M 400}

$1110 \pm 50$

Peat from Torpmosen $\left(56^{\circ} 32^{\prime} \mathrm{N}\right.$ Lat, $16^{\circ} 35^{\prime}$ E Long), Stenåsa parish, Alvaret, öland, Sweden. Sample from 38 to $42 \mathrm{~cm}$ below surface in bottom of a peat layer, $21 \mathrm{~cm}$ thick. Sample above the Secale curve. Coll. 1963. $\delta \mathrm{C}^{13}=$ $-27.8 \%$.

\section{U-484. Torpmosen M 397}

$$
\begin{array}{r}
540 \pm 70 \\
\text { A.D. } 1410 \\
620 \pm 40 \\
\text { A.D. } 1330
\end{array}
$$$$
\text { U-1017. Torpmosen M } 397
$$

Two measurements of peat from Torpmosen $\left(56^{\circ} 32^{\prime} \mathrm{N}\right.$ Lat, $16^{\circ} 35^{\prime} \mathrm{E}$ Long), Stenåsa parish, Alvaret, öland, Sweden. Sample from 21 to $25 \mathrm{~cm}$ below surface in top of a peat layer, $21 \mathrm{~cm}$ thick, in same section as U-444 and U-1003. Coll. 1963. $\delta \mathrm{C}^{13}=-19.0 \%$.

\section{Land Uplift series, Eastern Central Sweden}

Sediments from eastern Central Sweden, coll. from ancient lakes developed by isolation from the sea, to determine time and rate of land uplift in this part of Sweden. Described by Maj-Britt Florin (1945, 1946), Sten Florin (1944, 1948, 1963), Maj-Britt and Sten Florin (1940), L. von Post (1935), G. Brander (1935) and Lundegårdh and Lundqvist (1959).

General comment: samples from Kolundakärret show a higher age with decreasing depth in the sediment. This is probably due to a changing water level in the lake causing old sediments to be eroded and redeposited. The difference between two fractions U-433 and U-435 supports this explanation in one case.

$$
\begin{array}{lcc}
\text { U-432. Kolundakärret } 2,35 \text { to } 40 & 4600 \pm 100 \\
& & 2650 \text { в.c. } \\
\text { U-1004. Kolundakärret } 2,35 \text { to } 40 & 4830 \pm 90 \\
\text { Two measurements of fen dy from Kolundakärret }\left(59^{\circ} 18^{\prime} \text { N Lat, } 16^{\circ} 35^{\prime}\right.
\end{array}
$$


E Long), Stenkvista parish, Södermanland, Sweden, alt $30 \mathrm{~m}$, drainage level at about $35 \mathrm{~m}$. Sediment from level 35 to $40 \mathrm{~cm}$ below surface. Pollen analysis by Thorolf Candolin. Analyses imply that this sediment was deposited after the beginning of the Picea curve just below the zone boundary IX/VIII (Jessen). Coll. 1963 by S. Florin. $\delta \mathrm{C}^{13}=-26.6 \%$.

\section{U-433. Kolundakärret 2, 40 to $45 \mathrm{~g}$}

$$
\begin{aligned}
& 3610 \pm 120 \\
& 1660 \text { в.c. } \\
& 3520 \pm 50 \\
& 1570 \text { в.c. }
\end{aligned}
$$

\section{U-1005. Kolundakärret 2, 40 to $45 \mathrm{~g}$}

Two measurements of gyttja from Kolundakärret $\left(59^{\circ} 18^{\prime} \mathrm{N}\right.$ Lat, $16^{\circ} 35^{\prime}$ E Long), Stenkvista parish, Södermanland, Sweden, alt $30 \mathrm{~m}$, drainage level at about $35 \mathrm{~m}$. Sediment from 40 to $45 \mathrm{~cm}$ below surface. Pollen analysis by Candolin. Sample just below the increase of the Picea curve in Zone VIII (Jessen). Coll. 1963 by S. Florin. Comment: diluted. $\delta \mathrm{C}^{13}=-28.3 \%$.

\section{U-435. Kolundakärret 2, 40 to 45 w}

$3100 \pm 160$

Wood pieces from the same piece of core as U-433 and U-1005. Comment: diluted. $\delta \mathrm{C}^{13}=-28.3 \%$.

\section{U-430. Kolundakärret 2,55 to $60 \mathrm{~g}$}

$3300 \pm 90$ 1350 B.c.

Gyttja from Kolundakärret $\left(59^{\circ} 18^{\prime} \mathrm{N}\right.$ Lat, $16^{\circ} 35^{\prime} \mathrm{E}$ Long), Stenkvista parish, Södermanland, Sweden, alt $30 \mathrm{~m}$, drainage level at about $35 \mathrm{~m}$. Sediment from 55 to 60 below surface. Pollen analysis by Candolin. Sample below the continuous Picea curve in Zone VIII (Jessen). Coll. 1963 by S. Florin. $\delta \mathrm{C}^{13}=-28.7 \%$.

\section{U-436. Kolundakärret 2, 55 to $60 \mathrm{w}$}

$3330 \pm 120$

1380 в.с.

Wood pieces from the same piece of core as U-430. Comment: diluted. $\delta \mathrm{C}^{13}=-28.1 \%$.

\section{U-434. Bångsta-gärdet 45 to 50}

$4000 \pm 100$ 2050 в.c.

Clayey gyttja from Bångsta-gärdet $\left(59^{\circ} 12^{\prime} \mathrm{N}\right.$ Lat, $17^{\circ} 25^{\prime} \mathrm{E}$ Long $)$, Turinge parish, Södermanland, Sweden, drainage level at $12.6 \mathrm{~m}$. Sediment from 45 to $50 \mathrm{~cm}$ below surface. Pollen analysis by M. Tisell, diatom analysis by M.-B. Florin. Analyses imply brackish water and sample just below the increase of the Picea curve. Coll. by S. Florin 1959. $\delta \mathrm{C}^{13}=-23.6 \%$.

\section{U-437. Bålen 270 to 280}

$7080 \pm 350$

5130 в.c.

Gyttja from Bålen ( $59^{\circ} 04^{\prime}$ N Lat, $15^{\circ} 56^{\prime}$ E Long), V. Vingåker parish, Södermanland, Sweden, alt $39 \mathrm{~m}$. Sediment from 270 to $280 \mathrm{~cm}$ below surface. Pollen analysis as a team work and diatom analysis by Brander. Analyses imply brackish water and zone boundary VII/VIII (Jessen)-beginning of Tilia. Coll. 1959 by S. Florin. Comment: diluted. $\delta \mathrm{C}^{13}=-29.0 \%$. 
U-438. Kämstasjön 130 to 135

Gyttja from Kämstasjön $\left(59^{\circ} 12^{\prime} \mathrm{N}\right.$ Lat, $17^{\circ} 30^{\prime} \mathrm{E}$ Long), Turinge parish, Södermanland, Sweden, drainage level at alt 27.8 to $28.0 \mathrm{~m}$. Sample from 130 to $135 \mathrm{~cm}$ below surface. Pollen analysis by M. Tisell, diatom analysis by M.-B. Florin. Analyses imply change from brackish water to fresh water. Coll. 1959 by S. Florin. Comment: diluted. $\delta \mathrm{C}^{13}=-23.8 \%$.

\section{U-439. Kämstasjön 140 to 145}

$4990 \pm 260$ 3040 в.c.

Gyttja from Kämstasjön ( $59^{\circ} 12^{\prime} \mathrm{N}$ Lat, $17^{\circ} 30^{\prime} \mathrm{E}$ Long), Turinge parish, Södermanland, Sweden, drainage level at alt 27.8 to $28.0 \mathrm{~m}$. Sample from 140 to $145 \mathrm{~cm}$ below surface. Pollen analysis by M. Tisell, diatom analysis by M.-B. Florin. Analyses imply brackish water to fresh water. Coll. 1959 by S. Florin. Comment: diluted. $\delta \mathrm{C}^{13}=-29.0 \%$.

\section{U-466. Övre Sätramossen 382 to 390}

Gyttja from Övre Sätramossen $\left(58^{\circ} 56^{\prime} \mathrm{N}\right.$ Lat, $16^{\circ} 08^{\prime} \mathrm{E}$ Long $)$, Ö. Vingåker parish, Södermanland, Sweden, drainage level at alt $46.0 \mathrm{~m}$. Sample from 382 to $390 \mathrm{~cm}$ below surface. Pollen and diatom analyses by M.-B. Florin. Analyses imply brackish water and Zone VII (Jessen) below the decrease of Ulmus. Coll. 1959 by M.-B. and S. Florin. Comment: diluted. $\delta \mathrm{C}^{13}=$ $-23.6 \%$.

\section{Floran series}

Gyttja from the mire district "Floran" in northern Uppland, Sweden, to determine the land uplift and to study the vegetational history. This area, which covers the uppermost $140 \mathrm{~km}^{2}$ of the drainage area of the small river Forsmarksån, consists of about $40 \%$ fens and bogs, $8 \%$ lakes, about $50 \%$ forests, and only $1 \%$ cultivated ground. The lakes were originally (i.e. during the first time after the isolation from the sea due to land uplift) lime-rich but have become poorer in lime, and the gyttja deposits have been overlain by dy. Described by Ingmar (1963). Pollen analysis by Thorolf Candolin, diatom analysis by Ingmar. Coll. and subm. by Tord Ingmar, Växtbiologiska Inst., Uppsala Univ., Uppsala, Sweden.

General Comment: it is possible that the gyttja samples from the isolation stage and from the first lake stage systematically give somewhat too high ages due to the high content of lime in the water of the last sea stage and the first lake stage. The intention is to check this by special measurements.

\section{U-451. Sörbackenmossen 1 \\ $4990 \pm 90$ \\ 3040 в.c.}

Gyttja from the bog Sörbackenmossen $\left(60^{\circ} 20^{\prime} \mathrm{N}\right.$ Lat, $17^{\circ} 42^{\prime} \mathrm{E}$ Long $)$, Uppland, Sweden, alt $41 \mathrm{~m}$. Sample, $7 \mathrm{~cm}$ thick, from the boundary between brackish water gyttja and fresh water gyttja as checked by diatom analysis. Zone VIII (Jessen). Coll. 1963. $\delta \mathrm{C}^{13}=-21.1 \%$.

\section{U-225. Ulvsbo trusk 1}

Gyttja from the tarn Ulvsbo trusk $\left(60^{\circ} 19^{\prime} \mathrm{N}\right.$ Lat, $17^{\circ} 46^{\prime} \mathrm{E}$ Long $)$, 
Uppland, Sweden, alt $35 \mathrm{~m}$. Sample, $7 \mathrm{~cm}$ thick, from the boundary between brackish water and fresh water gyttja as checked by diatom analysis. Zone VIII (Jessen). Coll. 1962. $\delta \mathrm{C}^{13}=-22.5 \%$.

\section{U-226. Fälaren 1}

$$
4300 \pm 90
$$
2350 в.C.

Gyttja from the lake Fälaren $\left(60^{\circ} 20^{\prime} \mathrm{N}\right.$ Lat, $17^{\circ} 47^{\prime} \mathrm{E}$ Long $)$, Uppland, Sweden, alt $32 \mathrm{~m}$. Sample, $10 \mathrm{~cm}$ thick, from the boundary between brackish water and fresh water gyttja as checked by diatom analysis. Zone VIII (Jessen). Coll. 1963. $\delta \mathrm{C}^{13}=-22.4 \%$.

\section{U-455. Fälaren 2}

$$
4000 \pm 60
$$

Gyttja from the lake Fälaren $\left(60^{\circ} 20^{\prime} \mathrm{N}\right.$ Lat, $17^{\circ} 47^{\prime} \mathrm{E}$ Long), Uppland, Sweden, alt $32 \mathrm{~m}$. Sample, $5 \mathrm{~cm}$ thick, just above the boundary between brackish water gyttja and fresh water gyttja as checked by diatom analysis. Zone VIII (Jessen). Coll. 1964. $\delta \mathrm{C}^{13}=-18.7 \%$.

\section{U-454. Fälaren 3}

$$
4100 \pm 60
$$

Gyttja from the lake Fälaren $\left(60^{\circ} 20^{\prime} \mathrm{N}\right.$ Lat, $17^{\circ} 47^{\prime} \mathrm{E}$ Long), Uppland, Sweden, alt $32 \mathrm{~m}$. Sample, $5 \mathrm{~cm}$ thick, just below the boundary between brackish water gyttja and fresh water gyttja as checked by diatom analysis. Zone VIII (Jessen). Coll. 1964. $\delta \mathrm{C}^{13}=-21.5 \%$.

\section{U-452. Lilla Agnsjön 1}

Gyttja from the lake Lilla Agnsjön $\left(60^{\circ} 16^{\prime} \mathrm{N}\right.$ Lat, $17^{\circ} 49^{\prime} \mathrm{E}$ Long), Uppland, Sweden, alt $29 \mathrm{~m}$. Sample, $8 \mathrm{~cm}$ thick, from the boundary between brackish water gyttja and fresh water gyttja as checked by diatom analysis. Coll. 1963. Zone VIII (Jessen). $\delta \mathrm{C}^{13}=-22.7 \%$.

\section{U-471. Lilla Agnsjön 2}

Gyttja from the lake Lilla Agnsjön $\left(60^{\circ} 16^{\prime} \mathrm{N}\right.$ Lat, $17^{\circ} 49^{\prime} \mathrm{E}$ Long), Uppland, Sweden, alt $29 \mathrm{~m}$. Sample, $2 \mathrm{~cm}$ thick, just below the boundary between brackish water gyttja and fresh water gyttja as checked by diatom analysis. Zone VIII (Jessen). Coll. 1964. $\delta \mathrm{C}^{13}=-22.9 \%$.

\section{U-472. Ensjön 1}

$3760 \pm 90$

Gyttja from the lake Ensjön ( $60^{\circ} 24^{\prime} \mathrm{N}$ Lat, $17^{\circ} 51^{\prime} \mathrm{E}$ Long), Uppland, Sweden, alt $27 \mathrm{~m}$. Sample, $3 \mathrm{~cm}$ thick, from the boundary between brackish water gyttja and fresh water gyttja as checked by diatom analysis. Zone VIII $($ Jessen $) . \delta \mathrm{C}^{13}=-20.2 \%$.

\section{U-221. Rässan 2}

$$
3400 \pm 90
$$

Gyttja from the fen Rässan $\left(60^{\circ} 17^{\prime} \mathrm{N}\right.$ Lat, $17^{\circ} 53^{\prime} \mathrm{E}$ Long $)$, near Vikasjön, Uppland, Sweden, alt $27 \mathrm{~m}$. Sample, $2 \mathrm{~cm}$ thick, from the boundary between brackish water gyttja and fresh water gyttja as checked by diatom analysis. Sample below the beginning of the continuous curve of Picea in Zone VIII (Jessen). Coll. 1959. $\delta \mathrm{C}^{13}=-22.2 \%$. 


\section{U-220. Rässan 7}

$$
\begin{array}{r}
1750 \pm 80 \\
\text { A.D. } 200
\end{array}
$$

Gyttja fraction of Equisetum peat with gyttja from the fen Rässan $\left(60^{\circ}\right.$ $17^{\prime} \mathrm{N}$ Lat, $17^{\circ} 53^{\prime} \mathrm{E}$ Long), near Vikasjön, Uppland, Sweden, alt $27 \mathrm{~m}$. Sample, $4 \mathrm{~cm}$ thick, from the layer implying filling up of the previous lake. Sample from Zone IX (Jessen). Coll. 1962. $\delta \mathrm{C}^{13}=-23.6 \%$.

\section{U-223. Vikasjön 3}

$3140 \pm 100$

1190 в.C.

Gyttja from the lake Vikasjön $\left(60^{\circ} 17^{\prime} \mathrm{N}\right.$ Lat, $17^{\circ} 52^{\prime} \mathrm{E}$ Long), Uppland, Sweden, alt $27 \mathrm{~m}$. Sample, $7 \mathrm{~cm}$ thick, from the transition from greenish lake gyttja to reddish brown algal lake gyttja just at the beginning of the Picea tail but before the Quercus fall in Zone VIII (Jessen). Coll. 1962. $\delta \mathrm{C}^{13}=-25.0 \%$.

\section{U-222. Vikasjön 4}

$3130 \pm 80$

Gyttja from the lake Vikasion $\left(60^{\circ} 17^{\prime}\right.$ N Lat $17^{\circ} 52^{\prime}$ E Long), Uppland, Sweden, alt $27 \mathrm{~m}$. Sample, $10 \mathrm{~cm}$ thick, from the dark reddish brown algal lake gyttja just above the Quercus fall in Zone VIII (Jessen). Coll. 1962. $\delta \mathrm{C}^{13}=$ $-22.1 \%$.

\section{U-453. Vikasjön 5}

$$
2930 \pm 50
$$

Algal lake gyttja from the lake Vikasjön $\left(60^{\circ} 17^{\prime} \mathrm{N}\right.$ Lat, $17^{\circ} 52^{\prime} \mathrm{E}$ Long $)$, Uppland, Sweden, alt $27 \mathrm{~m}$. Sample, $3 \mathrm{~cm}$ thick, from the first pronounced Picea peak (Fromm, 1938) in Zone VIII (Jessen). Coll. 1963. $\delta \mathrm{C}^{13}=-24.8 \%$.

\section{U-1000. Västerängen 1}

$$
2870 \pm 60
$$

Gyttja from the ditched peat land Västerängen $\left(60^{\circ} 25^{\prime} \mathrm{N}\right.$ Lat, $14^{\circ} 44^{\prime} \mathrm{E}$ Long), Uppland, Sweden, alt $20 \mathrm{~m}$. Sample, $1 \mathrm{~cm}$ thick, from the uppermost gyttja and Phragmites layer also representing the isolation from the sea. Sample just below the marked increase of the Picea curve in the beginning of Zone IX (Jessen). Coll. 1963. $\delta \mathrm{C}^{13}=-28.0 \%$.

\section{U-450. Titirjaure, Padjelanta}

$4500 \pm 80$ 2550 в.c.

Wood of Pinus from Titirjaure $\left(67^{\circ} 20^{\prime}\right.$ N Lat, $17^{\circ}$ E Long), Padjelanta, Sweden, alt $700 \mathrm{~m}$. At present there is no pine forest at this altitude. Coll. 1963 by Å. Eklöf; subm. by Anders Rapp, Geografiska Inst., Uppsala Univ., Uppsala, Sweden. Comment: similar samples have been dated previously (Stockholm II, IV; Lundqvist, 1962). $\delta \mathrm{C}^{13}=-24.4 \%$.

II. ARCHAEOLOGIC SAMPLES

\section{A. Sweden}

\section{Gårdlösa series}

Charcoal from Gårdlösa No. $3\left(55^{\circ} 34^{\prime} \mathrm{N}\right.$ Lat, $14^{\circ} 08^{\prime} \mathrm{E}$ Long $)$, Smedstorp parish, Skåne, Sweden. Coll. 1963 and subm. by Berta Stjernquist, 
Lunds Historiska Mus., Lund, Sweden. The investigations of prehistoric cultplaces in the province of Skåne (Scania) is treated by Stjernquist (1964).
U-406. Gårdlösa 3, House V
$1530 \pm 80$
$\mathbf{U}-475$.
A.D. 420
U-1013.
$1400 \pm 80$
A.D. 550
$1390 \pm 60$

Charcoal from Gårdlösa 3 , House $\mathrm{V}$, found in a hearth, assumed to belong to late Iron Age because of some pottery and a bronze needle found in the house. Comment: the three results are given separately since the measurements were performed to check the reproducibility. The two first measurements were made with an interval of half a year in the same counter when the third result was obtained with another counter. $\delta \mathrm{C}^{13}=-24.0 \%$.

\section{U-476. Gårdlösa 3, House VI}

U-1014.

Two measurements of charcoal from Gårdlösa 3, House VI, found in the remains of the house foundation. $\delta \mathrm{C}^{13}=-23.6 \%$.

\section{U-1012. Gårdlösa 3, House VII}

$$
1490 \pm 40
$$$$
\text { A.D. } 460
$$

Charcoal from Gårdlösa 3, House VII, found in the house foundation, assumed to belong to late Iron Age because of some pottery, a golden bead, spindle whorls etc. $\delta \mathrm{C}^{13}=-22.8 \%$.

\section{U-410. Gårdlösa 3, Hearth 2}

$$
1710 \pm 80
$$

\section{A.D. 240}

Charcoal from Gårdlösa 3, Hearth 2, found together with burnt stones. Comment: the charcoal seems to derive from a branch at least $6 \mathrm{~cm}$ in diam. $\delta \mathrm{C}^{13}=-25.3 \%$.

\section{U-1011. Gårdlösa 3, Hearth 19}

$$
1760 \pm 50
$$

Charcoal from Gårdlösa 3, Hearth 19, found together with pottery. Comment: sample from a fragmentary wooden tray damaged by fire. $\delta \mathrm{C}^{13}=$ $-18.7 \%$.

\section{U-477. Gårdlösa 3, Hearth 27}

\section{U-1010.}

$1570 \pm 110$ A.D. 380

$$
\begin{array}{r}
1680 \\
\text { A.D. } 270
\end{array}
$$

Two measurements of charcoal from Gårdlösa 3, Hearth 27, found together with pottery. Comment: sample from a tray. $\delta \mathrm{C}^{13}=-25.6 \%$. 


\section{U-409. Glivarp bog 2757 A}

$$
2910 \pm 80
$$

960 в.c.

Resin cake from Glivarp bog ( $55^{\circ} 29^{\prime} \mathrm{N}$ Lat, $14^{\circ} 14.5^{\prime}$ E Long), Vallby parish, Skåne, Sweden. Subm. by Stjernquist. Comment : resin cakes have been dated previously, St-514, 515, 690, 929 and 957 (Stockholm IV and V) at ages between 2440 and 2945 в.P. $\delta \mathrm{C}^{13}=-33.8 \%$.

\section{U-411. Glivarp bog 2757 B $2975 \pm 85$}

The same resin cake as $\mathrm{U}-409$ but no pre-treatment. $\delta \mathrm{C}^{13}=-28.4 \%$.

\section{U-407. Gudahagen $3: 32$}

$2190 \pm 80$

Charcoal from Gudahagen $\left(56^{\circ} 10^{\prime} \mathrm{N}\right.$ Lat, $14^{\circ} 29^{\prime} \mathrm{E}$ Long), Näsum parish, Skåne, Sweden. Sample from a charcoal horizon in a bog at a depth of $32 \mathrm{~cm}$ in a test pit. Coll. 1962 and subm. by Stjernquist. $\delta \mathrm{C}^{13}=-28.3 \%$.

\section{U-249. Hassle Bösarp 15}

$945 \pm 70$

Wood from Hassle Bösarp hog ( $54^{\circ} 27^{\prime} \mathrm{N}$ Lat, $12^{\circ} 31^{\prime}$ E Long), Hassle Bösarp parish, Skåne, Sweden. Sample from a large piece of wood which was found at a higher level than several artifacts. $\delta \mathrm{C}^{13}=-21.0 \%$.

\section{Dragby series}

Resin and charcoal from Dragby ( $59^{\circ} 59^{\prime} \mathrm{N}$ Lat, $17^{\circ} 35^{\prime} \mathrm{E}$ Long), Skuttunge parish, Sweden. Results of the excavations and geological investigations are given by several authors (for a list see Uppsala IV). Other samples have been dated previously (Uppsala II, III and IV; Stockholm IV). Subm. by Mårten Stenberger, Inst. för Nordisk och Jämförande Fornkunskap, Uppsala Univ., Uppsala, Sweden.

\section{U-1006. Dragby 380 B}

$3010 \pm 60$ 1060 в.c.

Charcoal from a grave covered by a stone paving. Coll. 1963 by Ingvar Sjögren. $\delta \mathrm{C}^{13}=-20.9 \%$.

\section{U-401. Dragby 401}

$$
\begin{array}{r}
1730 \\
\text { A.D. } 220
\end{array}
$$

Resin from a grave belonging to Early Iron Age or Migration Period. Coll. 1963. $\delta \mathrm{C}^{13}=-27.6 \%$.

\section{U-408. Dragby 403}

$$
2260 \pm 100
$$

Resin from a grave belonging to Early Iron Age or Migration Period. Coll. 1963. $\delta \mathrm{C}^{13}=-26.2 \%$.

\section{U-402. Dragby $65 \mathrm{D}$}

$$
2910 \pm 80
$$

Charcoal from Pit No. 1 below layer of brittle burnt stones on bottom of pit probably used for cooking. Coll. 1963 by Per Kåks. $\delta \mathrm{C}^{13}=-25.2 \%$. 


\section{U-405. Dragby $65 \mathrm{E}$}

Charcoal from Pit No. 2 below layer of brittle burnt stones on bottom of a pit probably used for cooking. Coll. 1963 by Per Kåks. $\delta \mathrm{C}^{13}=-24.6 \%$.

Date lists:

REFERENCLS

Stockholm II Östlund, 1959

Stockholm IV Engstrand and Östlund, 1962

Stockholm V Östlund and Engstrand, 1963

Uppsala I Olsson, 1959

Uppsala II Olsson, 1960

Uppsala III Olsson and others, 1961

Uppsala IV Olsson and Kilicci, 1964

S.G.U. is Sveriges geologiska undersökning.

G.F.F. is Geologiska föreningens i Stockholm förhandlingar.

Brander, G., 1935, Die baltische Diatomeen-Succession des Bålen-Beckens, in Bålen-SeeStudien des Geologischen Instituts der Stockholms Högskola. 2.: G.F.F., v. 57, p. 318340 .

Craig, Harmon, 1961, Mass-spectrometer analyses of radiocarbon standards: Radiocarbon, v. 3 , p. $1-3$.

Engstrand, L. G., and östlund, H. G., 1962, Stockholm natural radiocarbon measurements IV: Radiocarbon, v. 4, p. 115-136.

Eriksson, K. G., in press, Rept. Swedish Deep-Sea Exped., v. 8, no. 7.

Erikson, K. G., and Olsson, I. U., 1963, Some problems in connection with $\mathrm{C}^{14}$ dating of tests of Foraminifera: Bull. Geol. Inst. Uppsala, v. 42, p. 1-13.

Feyling-Hanssen, R. W., 1955, Stratigraphy of the marine Late-Pleistocene of Billefjorden, Vestspitsbergen: Norsk Polarinst. skr., no. 107, 186 p. - 1955, Late-Pleistocene deposits at Kapp Wijk, Vestspitsbergen: Norsk Polarinst. skr., no. $108,21 \mathrm{p}$.

Feyling-Hanssen, R. W., and Jørstad, F. A., 1950, Quaternary fossils from the Sassen-area in Isfjorden, West-Spitsbergen: Norsk Polarinst. skr., no. 94, 85 p.

Feyling-Hanssen, R. W., and Olsson, Ingrid, 1959-1960, Five radiocarbon datings of Post Glacial shorelines in Central Spitsbergen: Norsk Geog. Tidsskr., v. 17, p. 122-131.

Florin, Maj-Britt, 1945, Skärgårdstall och "strandskog" i västra Södermanlands pollendiagram: G.F.F., v. 67 , p. 511-533.

gram: 1946, Clypeusfloran i postglaciala fornsjölagerföljder i östra Mellansverige: G.F.F., v. 68 , p. $429-458$.

Florin, Maj-Britt and Florin, Sten, 1940, Istidsminnen och stenåldershygden: Turingeboken, en sockenbeskrivning utgiven med anledning av Nykvarns bruks 350-årsjubileum 1940, v. 1 , Södertälje, p. 43-74.

Florin, Sten, 1944, Havsstrandens förskjutningar och bebyggelseutvecklingen i östra Mellansverige under senkvartär tid. I. Allmän översikt: G.F.F., v. 66, p. 551-634.

1948, Havsstrandens förskjutningar och bebyggelseutvecklingen i östra Mellansverige under senkvartär tid. II. De baltiska strandbildningarna och stenåldersboplatsen vid Dammstugan nära Katrineholm: G.F.F., v. 70, p. 17-202. 1963, Land och vatten i forntiden: Stenkvista. En socken i Sörmland, p. 101147.

Fromm, Erik, 1938, Geochronologisch datierte Pollendiagramme und Diatoméanalysen aus Angermanland: G.F.F., v. 60 , p. 365-381.

Ingmar, Tord, 1963, Från Havsvik till mosse: Sveriges Naturs Årsbok, v. 54, p. 155-177.

Kjartansson, Gudmundur, Thorarinsson, Sigurdur, and Einarsson, Thorleifur, 1964, $\mathrm{C}^{14}$ aldursákvardanir á sýnishornum vardandi islenzka kvarterjardfraedi $\left(\mathrm{C}^{14}\right.$ datings of Quaternary deposits in Iceland) : Náttúrufrædingurinn, v. 34, p. 97-145.

Königsson, L.-K., 1962, Dröstorps mose: G.F.F., v. 84, no. 2, p. 88-118.

Lundegårdh, P. H., and Lundqvist, Gösta, 1959, Beskrivning till geologiska kartbladet Eskilstuna: S.G.U. Ser, Aa, no. 200, p. 1-125.

Lundqvist, Gösta, 1962, Geological radiocarbon datings from the Stockholm station: S.G.U. Ser. C, no. 589; årsbok 56, no. 5, 23 p. 
Olsson, Ingrid, 1958, A $\mathrm{C}^{14}$ dating station using the $\mathrm{CO}_{2}$ proportional counting method: Arkiv Fysik, v. 13, p. 37-60.

1959, Uppsala natural radiocarbon measurements I: Am. Jour. Sci. Radioc. Supp., v. 1, p. 87-102. Supp., v. 2, p. 112-128.

Olsson, Ingrid, Cazeneuve, Horacio, Gustavsson, John and Karlén, Ingvar, 1961, Uppsala natural radiocarbon measurements III: Radiocarbon, v. 3, p. 81-85.

Olsson, Ingrid, and Kilicci, Serap, 1964, Uppsala natural radiocarbon measurements IV: Radiocarbon, v. 6, p. 291-307.

Olsson, I. U., and Eriksson, K. G., in press, Remarks on $\mathrm{C}^{14}$ dating of shell material in sea sediment: Progress in Oceanography, v. 3.

Östlund, G. H., 1959, Stockholm natural radiocarbon measurements II: Am. Jour. Sci. Radioc. Supp., v. 1, p. 35-44.

Östlund, G. H., and Engstrand, L. G., 1963, Stockholm natural radiocarbon measurements V: Radiocarbon, v. 5, p. 203-227.

von Post, Lennart, 1935, Der Bålen-See und die Bålen-See-Studien, in Bålen-See-Studien des Geologischen Instituts der Stockholms Högskola I.: G.F.F., v. 57, p. 302-317.

Stjernquist, Berta, 1964, New light on spring-cults in Scandinavian prehistory: Archaeology, v. 17 , no. 3 , p. 180-184.

Todd, Ruth, 1958, Foraminifera from Western Mediterranean deep-sea cores: Rept. Swedish Deep-Sea Exped., v. 8, no. 3, p. 167-217. 